\title{
A NEW SPECIES OF CYCAS (CYCADACEAE) FROM THE PHILIPPINES
}

\author{
D.A. MADULID ${ }^{1} \&$ E.M.G. AGOO $^{2}$
}

\begin{abstract}
SUMMARY
A new species, Cycas zambalensis Madulid \& Agoo, is described from an ultrabasic hilly grassland in Zambales, Luzon Island, Philippines.
\end{abstract}

Key words: Cycas zambalensis, Philippines, threatened Philippine plant.

\section{INTRODUCTION}

In their taxonomic revision of the genus Cycas L., De Laubenfels \& Adema (1998) listed four species from the Philippines, i.e., C. riuminiana Porte ex Regel, C. silvestris K.D. Hill, C. edentata de Laub., and C. wadei Merr. (endemic). Except for C. wadei, which is dominant in cogonal or Imperata cylindrica (Gramineae) dominated areas in Culion Island, Northern Palawan, the other species are commonly found in coastal areas or farther inland in lowland evergreen rain forests in many parts of the country.

A distinct population of Cycas was discovered by the authors in the course of establishing the current distribution of Cycas riuminiana (syn. Cycas chamberlainii) in Luzon Island, a research funded by the Haribon Foundation's Threatened Species Program. The population dominates the hilly grasslands of the Zambales Peninsula, which is distinct from the lowland evergreen rain forests of the Bataan-Zambales mountain range.

The soils in the area are ultramafic and rich in chromite deposits. The San Antonio Massif is classified as a peridotite-gabbro association (Bureau of Mines and Geosciences, 1982). There are two pronounced seasons in the province: the dry season which is from November to April and the wet season for the rest of the year. Maximum rainfall occurs from June to September which coincides with the southwest monsoon (Kintanar, 1984).

The steep and rugged hills in Zambales where the plants are found are remote, inaccessible and difficult to climb. It is said that occasionally the grassy hillsides are burnt (at least once a year) to promote the new growth of grass for cattle and goats. Recently, there is a demand for the horticultural trade of this species and seedlings or young plants are collected and sold in the market. The leaves of the species are also used by the local people in religious rituals during the Lenten season.

1) Philippine National Museum, P.O. Box 2659, Manila, Philippines.

2) Biology Department, De La Salle University-Manila, 2401 Taft Avenue, Manila, Philippines. 


\section{TAXONOMIC TREATMENT}

\section{Cycas zambalensis Madulid \& Agoo, spec. nov.}

Cycas riuminianae simile sed differt pinnis brevibus tomentosis rigidis $\mathrm{V}$-formatis dispositis et seminibus parvioribus ovatis laterale leviter complanatis. - Typus: Madulid \& Agoo PNH 173358 (holo PNH), Philippines, Zambales, San Antonio, 2005.

Small tree to $3 \mathrm{~m}$ high, $30 \mathrm{~cm}$ diam., usually single stemmed, occasionally branching. Leaves to $105 \mathrm{~cm}$; pinnae $66-88$ pairs, the two rows V-shaped or raised in an angle; petiole to $32 \mathrm{~cm}$ long, thorns less than $5 \mathrm{~mm}$ long, yellowish, found throughout the length. Pinnae $12-21$ by $0.5-0.8 \mathrm{~cm}$, dark green, shiny, rigid and stiff, margin straight, sometimes slightly bent, midrib pronounced below, hairs sparsely present on both surfaces, brownish. Pollen cone brownish orange, ovoid to long ovoid, tapering, to 25 by $12 \mathrm{~cm}$; peduncle to $6 \mathrm{~cm}$. Microsporophylls $3-5$ by $1-2 \mathrm{~mm}$, sterile apex $3 \mathrm{~mm}$; acumen or beak 5-10 mm. Megasporophyll with 2 or 3 pairs of ovules, to $26-35 \mathrm{~cm}$, very lanate; sterile part ovate, to 8 by $6-7 \mathrm{~cm}$, comb-teeth $9-11$ on each side, length on lower side $1.1-1.5 \mathrm{~cm}$, on upper side to $1.5 \mathrm{~cm}$; acumen triangular, to 35 by $60 \mathrm{~mm}$. Seeds slightly flattened-ovoid, to 3.5 by $3 \mathrm{~cm}$; sarcotesta yellow when mature; fibrous layer absent; sclerotesta smooth, crest not prominent; endocarp long ovoid, fleshy, soft, translucent turning white when mature.

Distribution - San Antonio, Kawag, Bucao, Zambales NW Luzon. Endemic.

Habitat - In open grasslands, on ultrabasic hills.

Note - The species differs from $C$. riuminiana in having narrower pinnae, longer than wide sterile part of the megasporophyll, larger apical undivided part or acumen of the megasporophyll, very lanate megasporophylls, and tomentose pinnae and rachis. The hairs persist even in dried specimens. The pinnae are short, rigid and stiff, and arranged in V-shape along the rachis. The seeds are slightly flattened and the young endocarp is translucent and watery and becomes white and starchy when mature. It is slightly sweet in taste and occasionally eaten.

\section{DISCUSSION}

The species is easily distinguished from the other Philippine Cycas in having tomentose pinnae and rachis. This characteristic is also observed in C. furfuracea and C. calcicola, but these species are found in Australia in open habitats and on other types of specialized soils. The pinnae of $C$. zambalensis are also rigid and stiff, and the two rows are raised in an angle forming a trough. This is very pronounced when the leaves are still young but gradually it becomes lesser pronounced when the leaves are more mature. Based on these characteristics, the young individuals of $C$. zambalensis resemble C. taitungensis (referred more popularly as $C$. revoluta), a common ornamental plant in the country.

Classified under subgenus Pectinata de Laub., Cycas zambalensis is very similar to $C$. riuminiana (syn: $C$. chamberlainii), also found in the Philippines, in having long petioles (at least $25 \mathrm{~cm}$ ), megasporophylls very woolly, and comb-teeth not more than 12 pairs, with length of not less than $5 \mathrm{~mm}$ and not more than $20 \mathrm{~mm}$. 

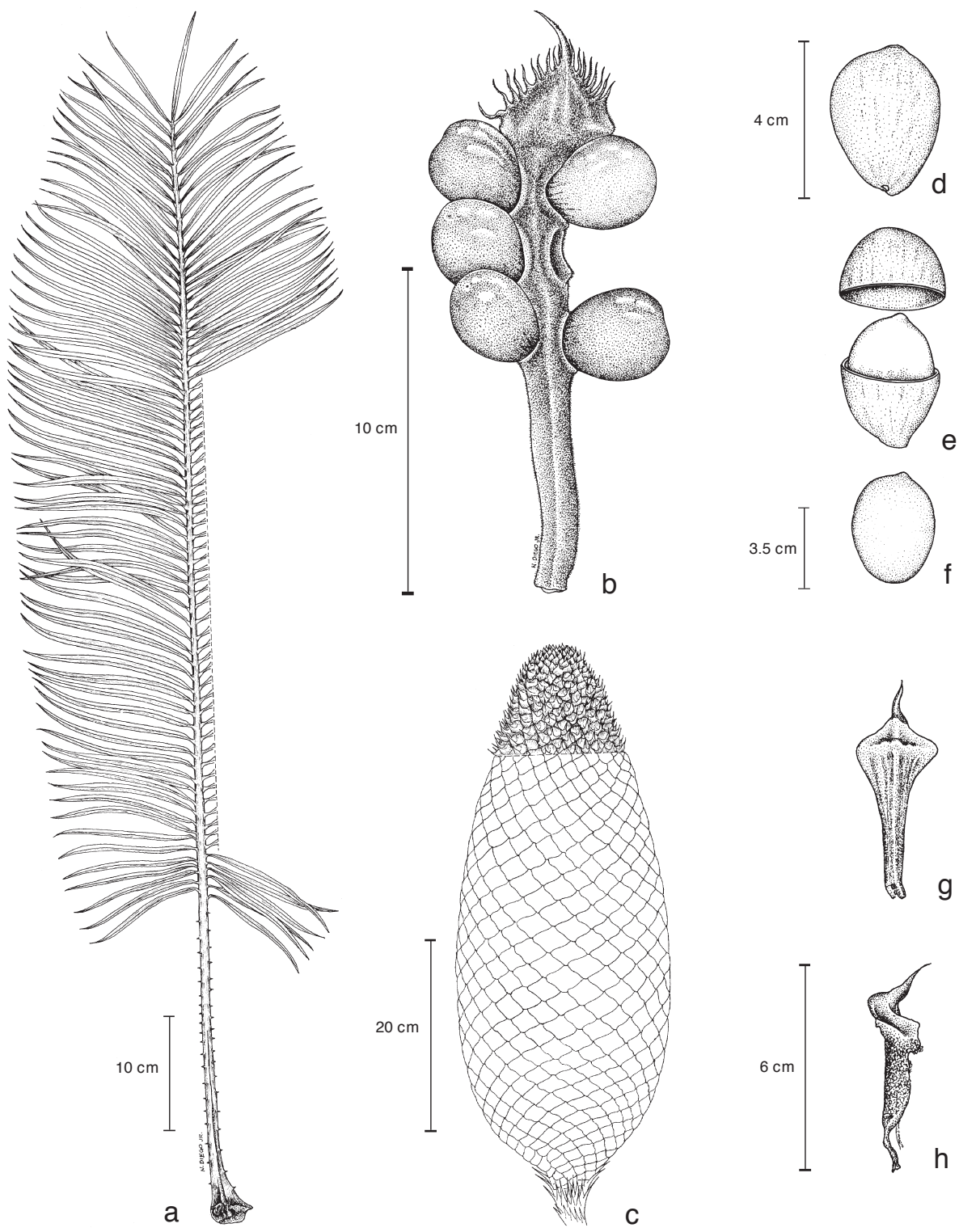

Fig. 1. Cycas zambalensis Madulid \& Agoo. a. Leaf; b. megasporophyll with seeds; c. male cone; d. bare seed; e. opened seed showing endosperm; f. endocarp; g. front view of microsporophyll; h. side view of microsporophyll (all: Madulid \& Agoo PNH 173358, PNH).

It can be differentiated from $C$. riuminiana with its narrower pinnae (5-8 mm), longer than wide sterile part of the megasporophyll, larger apical undivided part or acumen of the megasporophyll, (to 35 by $60 \mathrm{~mm}$ ), very lanate megasporophylls, and tomentose pinnae and rachis. 
Cycas zambalensis is restricted to the ultrabasic grassy hills of Zambales, a distinct biogeographic region in the western part of Luzon Island. The plants are usually scattered wide apart on the hillsides and do not form distinct groups. Detailed population studies have yet to be made in the areas where the species is found and this is being planned by the authors in the future. The very limited distribution of $C$. zambalensis, changing land use of the habitat of the species, and increasing pressure from collection for the horticultural trade are serious threats to the species. It is considered a critically endangered species. The effect of occasional fire to the population has yet to be evaluated.

\section{ACKNOWLEDGEMENTS}

The authors are grateful to Virgilio Linis for helping in collecting the plant; Manuel Santiago, Barangay Captain of Pundakit, San Antonio, Zambales, for lending support for the fieldwork activities, CENRO office in Cabangan, Zambales and the Regional Office of DENR, San Fernando, Pampanga for their interest in the project. Raymond Fuentes and Erwin Sebastian assisted us during the fieldwork. We acknowledge Dr. F. Adema for reviewing and providing valuable comments to this article and Dr. J.F. Veldkamp (both Nationaal Herbarium Nederland) for providing the Latin diagnosis.

This research project is co-funded by the Haribon Foundation's Threatened Species Program (supported by the Critical Ecosystem Partnership Fund), the De La Salle University-Manila and the Philippine National Museum.

\section{REFERENCES}

Bureau of Mines and Geosciences. 1982. Geology and Mineral Resources of the Philippines. 3 Vols. Bureau of Mines and Geosciences, Manila.

De Laubenfels, D.J. \& F. Adema. 1998. A taxonomic revision of the genera Cycas and Epicycas gen. nov. (Cycadaceae). Blumea 43: 351-400.

Kintanar, R. 1984. Climate of the Philippines. PAGASA, Quezon City. 